Article

\title{
Antimalarial Activity of Methanolic Leaf Extract of Piper betle L.
}

\author{
Abdulelah H. Al-Adhroey ${ }^{1, *}$, Zurainee M. Nor ${ }^{1}$, Hesham M. Al-Mekhlafi ${ }^{1}$, Adel A. Amran ${ }^{2}$ \\ and Rohela Mahmud ${ }^{1}$
}

1 Department of Parasitology, Faculty of Medicine, University of Malaya, Kuala Lumpur 50603, Malaysia; E-Mails: zuraineemn@um.edu.my (Z.M.N.); halmekhlafi@yahoo.my (H.M.A.); rohela@ummc.edu.my (R.M.)

2 Department of Physiology, Faculty of Medicine, Universiti Kebangsaan Malaysia, Jalan Raja Muda Abdul Aziz, Kuala Lumpur 50300, Malaysia; E-Mail adel.emran@yahoo.com (A.A.A.)

* Author to whom correspondence should be addressed; E-Mail: husssien75@yahoo.com; Tel.: +6-03-79673789; Fax: +6-03-79674754.

Received: 25 November 2010; in revised form: 18 December 2010 / Accepted: 21 December 2010 / Published: 28 December 2010

\begin{abstract}
The need for new compounds active against malaria parasites is made more urgent by the rapid spread of drug-resistance to available antimalarial drugs. The crude methanol extract of Piper betle leaves $(50-400 \mathrm{mg} / \mathrm{kg})$ was investigated for its antimalarial activity against Plasmodium berghei (NK65) during early and established infections. The phytochemical and antioxidant potentials of the crude extract were evaluated to elucidate the possibilities of its antimalarial effects. The safety of the extract was also investigated in ICR mice of both sexes by the acute oral toxicity limit test. The leaf extract demonstrated significant $(P<0.05)$ schizonticidal activity in all three antimalarial evaluation models. Phytochemical screening showed that the leaf extract contains some vital antiplasmodial chemical constituents. The extract also exhibited a potent ability to scavenge the free radicals. The results of acute toxicity showed that the methanol extract of Piper betle leaves is toxicologically safe by oral administration. The results suggest that the Malaysian folklorical medicinal application of the extract of Piper betle leaf has a pharmacological basis.
\end{abstract}

Keywords: Piper betle; methanolic extract; antimalarial activity 


\section{Introduction}

Malaria, a tropical blood-borne protozoan disease caused by parasites of the genus Plasmodium, is one of the most important infectious diseases in the World. Nowadays, anti-malarial drug resistance has become one of the most important challenges to malaria control efforts [1]. Drug resistance is responsible for the spread of malaria to new areas, the recurrence of malaria in areas where the disease had been eradicated and plays an important role in the occurrence and severity of epidemics in some parts of the World [2]. Considering this growing problem, there is a broad consensus as to the need to develop new anti-malarial drugs which can cope with the spread of drug resistant malarial parasites $[3,4]$. The ethnomedical approach to the search for new anti-malarial drugs from plant sources has proved to be more predictive, where the most important modern anti-malarial drugs are derived from the medicinal plants known to have ethnomedical standing [5-8].

Piper betle Linn is a liana belonging to the Piperaceae family. It is cultivated in most of South and Southeast Asia and valued both as a mild stimulant and for its medicinal properties. In Peninsular Malaysia, the leaves of Piper betle are also used by the rural population as an antimalarial remedy [9]. The leaves are chewed alone or with other plant materials. Recently, the leaves have been reported to exhibit many pharmacological effects including anti-bacterial [10], anti-leishmanial [11], anti-filarial [12] and anti-fungal [13] properties. This study, therefore, aims to find out if Piper betle leaves possess in vivo anti-malarial effects against the laboratory malaria model, Plasmodium berghei.

\section{Results and Discussion}

\subsection{Phytochemical screening}

Phytochemical screening of the methanol extract of Piper betle leaves revealed that the leaf extract contains alkaloids, terpenes, anthraquinones, flavonoids, tannins, saponins and steroids. Phytochemical compounds such as alkaloids are commonly implicated in the antiplasmodial activity of many plants [14-17]. Terpenes or terpenoids have been identified as active antiprotozal and antimalarial agents in many pharmacological studies [18-21]. Flavonoids are the other forms of Piper betle phenolic structures. Flavonoids revealed significant anti-parasitic activities against different parasite strains of malaria, trypanosome and leishmania [22-24]. Derivatives of 9,10-anthraquinone include many important drugs including antimalarials like rufigallol [25]. These chemical compounds which were found in this extract may be acting singly or in synergy with one another to exert the observed antiplasmodial activity of Piper betle.

\subsection{Antioxidant capacity}

Investigation on the antioxidant activity of the extract against 1,1-diphenyl-2-picrylhydrazyl radicals (DPPH) showed that it exhibited a strong radical scavenging capacity, comparable to that of controls. At a concentration of $12.5 \mu \mathrm{g} / \mathrm{mL}$, the scavenging activity of the methanol extract of the leaves reached $82.56 \pm 1.50 \%$, while at the same concentration, those of the ascorbic and gallic acids controls were $72.25 \pm 2.44$ and $73.03 \pm 2.27 \%$, respectively (Figure 1). The potent antioxidant capacity exhibited by the Piper betle leaves may be due to the phenolic compounds in this extract, 
such as chavicol, chavibetol, chavibetol acetate and eugenol [26-28]. The antioxidant effect of the Piper betle leaf extract may represent another mechanism that contributes to its anti-malarial activity. Piper betle leaf extract decreases nitric oxide (NO) production in macrophages [29]. According to Daubener [30], the inhibition of NO starves the parasite of an essential amino acid, leading to its death by increasing tryptophan degradation through indolamine deoxygenase induction in human peritoneal macrophages.

Figure 1. DPPH radical scavenging activity of methanol extract of Piper betle leaves. Absorbance values represent means of triplicate tests of the different concentrations analyzed.

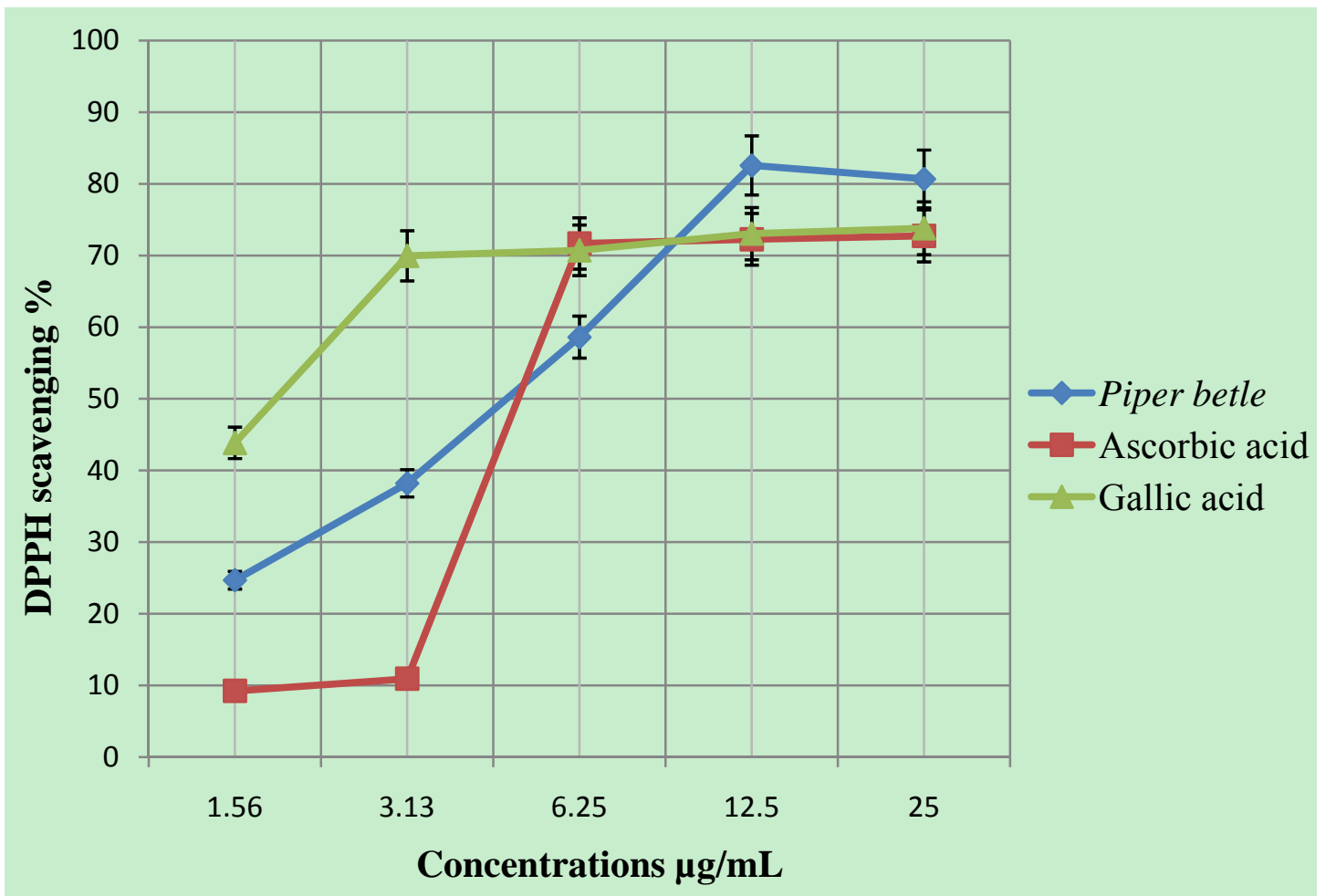

\subsection{Median lethal dose}

No deaths occurred during the observation period. Some symptoms were observed 1 hour following administration of the extract. Ataxia and piloerection were noted in males and females; all of which resolved by 3 hours after administration. No abnormal general symptoms were observed in the extract treated groups. All animals gained body weight at the end of the 14-day observation period. Administration of the leaf extract at $5,000 \mathrm{mg} / \mathrm{kg}$ had no effect on the necropsy findings. Histopathological lesions were not observed in any of the main organs of the mice (Figure 2).

Based on these results the median lethal dose $\left(\mathrm{LD}_{50}\right)$ of the methanol extract of Piper betle leaf after single oral administration in male and female ICR mice was found to be greater than $5,000 \mathrm{mg} / \mathrm{kg}$ body weight. The $\mathrm{LD}_{50}$ value of more than $5,000 \mathrm{mg} / \mathrm{kg}$ showed that the extract is practically safe [31,32]. 
Figure 2. Photomicrographs of the sections of the liver $\times 200$, lung stroma $\times 200$, kidney $\times$ 200 and heart $\times 100$ showing normal features in mice treated with $5,000 \mathrm{mg} / \mathrm{kg}$ of methanol extract of Piper betle leaves.

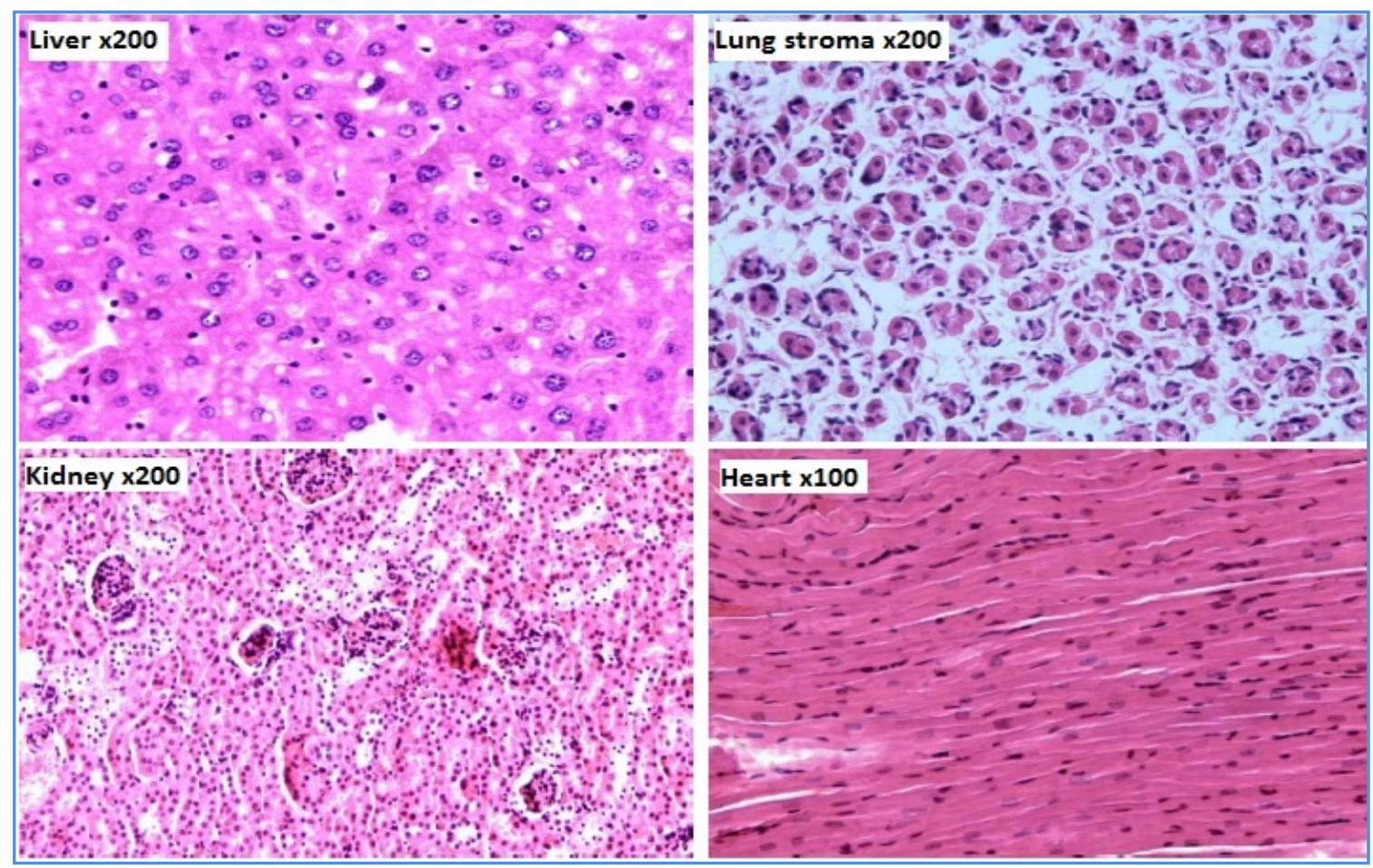

\subsection{In vivo antimalarial activity}

The leaf extract demonstrated significant $(P<0.05)$ schizonticidal activity in the all three models of the antimalarial evaluations. The suppression of parasitaemia by chloroquine at $20 \mathrm{mg} / \mathrm{kg} / \mathrm{day}$ was in agreement with a previous study by Muregi et al. [33].

\subsubsection{Suppressive anti-malarial activity}

The in vivo antiplasmodial activity of four different doses $(50,100,200$, and $400 \mathrm{mg} / \mathrm{kg}$ ) of the methanol extract of Piper betle leaves administrated orally showed a dose-dependent chemosuppressive activity which ranged between $36.47 \%$ to $82.31 \%$ in all groups of mice (Table 1 ). A considerably high degree of chemosuppression was shown by the 200 and $400 \mathrm{mg} / \mathrm{kg}$ doses which significantly decreased the parasitaemia of the infected mice when compared to control $(P<0.01)$.

Table 1. Effects of methanol extract of Piper betle on early malaria infection.

\begin{tabular}{lllll}
\hline Extract/drug & Dose & \% Parasitaemia & $\begin{array}{l}\text { \%Chemo- } \\
\text { suppression }\end{array}$ & Significance \\
\hline Control (dist. water) & $0.2 \mathrm{~mL}$ & $5.10 \pm 0.33$ & & \\
Piper betle Leaf extract & $50 \mathrm{mg} / \mathrm{kg}$ & $3.24 \pm 0.82$ & 36.47 & $\mathrm{~ns}$ \\
& $100 \mathrm{mg} / \mathrm{kg}$ & $2.40 \pm 0.68$ & 52.94 & $P<0.05$ \\
& $200 \mathrm{mg} / \mathrm{kg}$ & $1.50 \pm 0.63$ & 70.51 & $P<0.01$ \\
& $400 \mathrm{mg} / \mathrm{kg}$ & $0.90 \pm 0.33$ & 82.31 & $P<0.01$ \\
Chloroquine & $20 \mathrm{mg} / \mathrm{kg}$ & 0.00 & 100 & \\
\hline
\end{tabular}




\subsubsection{Curative anti-malarial activity}

The results indicated that the methanol extract of Piper betle leaves exhibited dose-dependent chemosuppression in parasitaemia. This curative chemosuppression of the treated groups was statistically significant $(P<0.05)$ when compared to the control. The control group showed daily increases in parasitaemia reaching $12.8 \%$ on the seventh day of infection (Figure 3). The chemosuppression effects for the treated groups on the sixth day of infection were $37.50,45.83,66.46$ and 70.63 for $50,100,200$ and $400 \mathrm{mg} / \mathrm{kg}$, respectively (Table 2). These treated groups (50 to $400 \mathrm{mg} / \mathrm{kg}$ ) of mice also had longer survival times which ranged between $14.40 \pm 0.93$ days and 19.00 \pm 1.22 days as compared to the control with $13.6 \pm 0.82$ days. The chloroquine-treated group had a mean survival time of $27.20 \pm 2.33$ days (Table 3 ).

Table 2. Activity of Piper betle on established malaria infection.

\begin{tabular}{lllll}
\hline \multicolumn{1}{c}{ Extract/drug } & Dose & \% Parasitaemia & $\begin{array}{l}\text { \%Chemo- } \\
\text { suppression }\end{array}$ & Significance \\
\hline Control (dist. water) & $0.2 \mathrm{~mL}$ & $9.60 \pm 0.93$ & & \\
Piper betle Leaf extract & $50 \mathrm{mg} / \mathrm{kg}$ & $6.00 \pm 0.84$ & 37.50 & $P<0.05$ \\
& $100 \mathrm{mg} / \mathrm{kg}$ & $5.20 \pm 0.92$ & 45.83 & $P<0.05$ \\
& $200 \mathrm{mg} / \mathrm{kg}$ & $3.22 \pm 0.95$ & 66.46 & $P<0.001$ \\
& $400 \mathrm{mg} / \mathrm{kg}$ & $2.82 \pm 0.84$ & 70.63 & $P<0.05$ \\
Chloroquine & $20 \mathrm{mg} / \mathrm{kg}$ & 00 & 100 & \\
\hline
\end{tabular}

Figure 3. Comparison of parasitaemia chemosuppression of the extract-treated groups and control from D3 until D7 after infection.

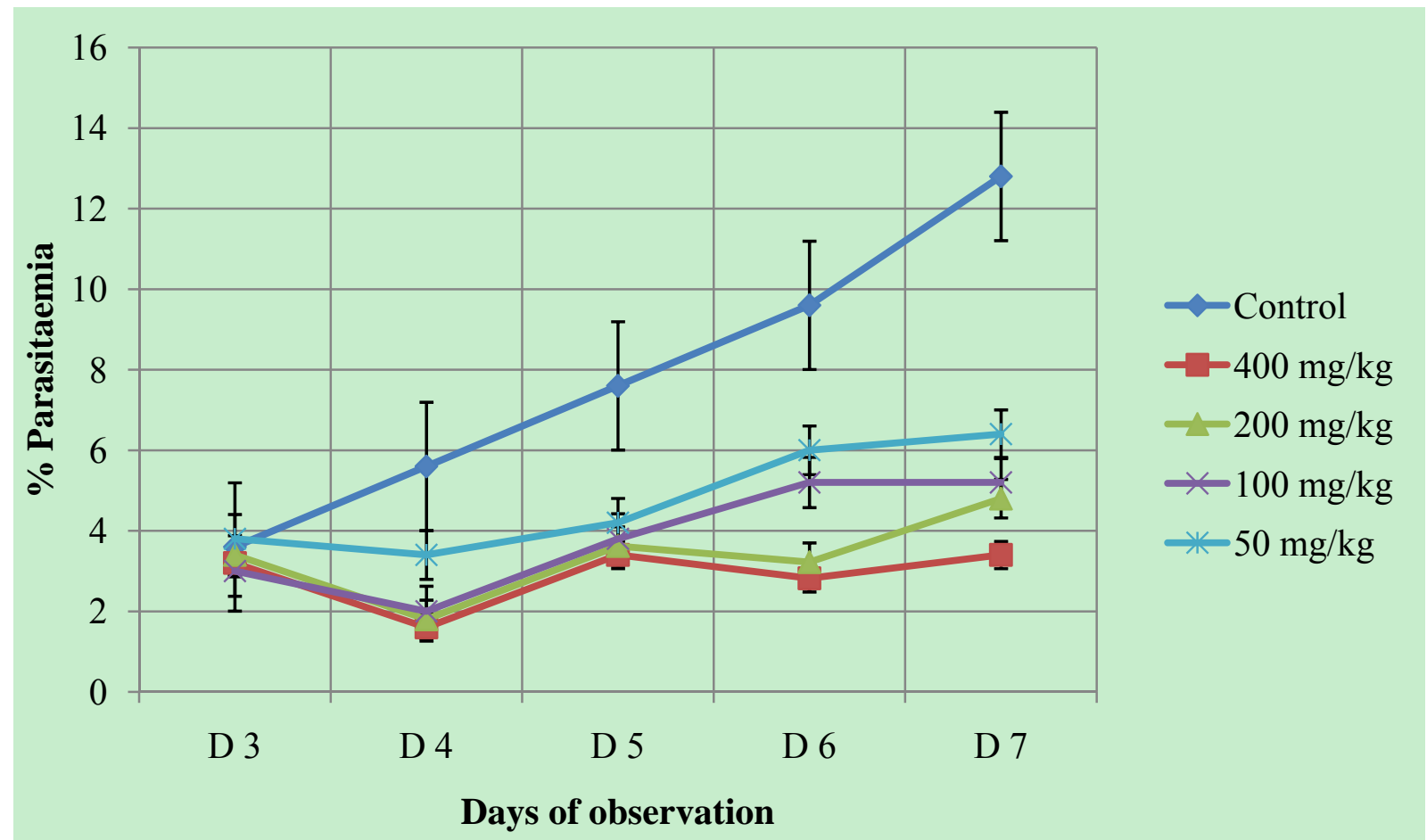


Table 3. Mean survival period of mice treated with Piper betle in established malaria infection.

\begin{tabular}{lccc}
\hline Drug/extract & Dose & Survival time (days) & Significance \\
\hline Control (dist. water) & $0.2 \mathrm{~mL}$ & $13.60 \pm 0.51$ & \\
Piper betle Leaf extract & $50 \mathrm{mg} / \mathrm{kg}$ & $14.40 \pm 0.93$ & $\mathrm{~ns}$ \\
& $100 \mathrm{mg} / \mathrm{kg}$ & $15.20 \pm 1.16$ & $\mathrm{~ns}$ \\
& $200 \mathrm{mg} / \mathrm{kg}$ & $17.20 \pm 1.56$ & $\mathrm{~ns}$ \\
& $400 \mathrm{mg} / \mathrm{kg}$ & $19.00 \pm 1.22$ & $P<0.01$ \\
Chloroquine & $20 \mathrm{mg} / \mathrm{kg}$ & $27.20 \pm 2.33$ & $P<0.001$ \\
\hline
\end{tabular}

\subsubsection{Prophylactic anti-malarial activity}

The methanol extract of Piper betle exerted a dose-dependent prophylactic activity at the different doses employed resulting in significant $(\mathrm{P}<0.05)$ reduction of parasitaemia in extract treated groups when compared to control. It exerted $19.57,34.78,52.17$ and $70.88 \%$ chemosuppressions at doses of 50, 100, 200 and $400 \mathrm{mg} / \mathrm{kg}$, respectively. The chemosuppression shown by the highest dose of the extract $(400 \mathrm{mg} / \mathrm{kg}$ ) was comparable to that of the standard drug, pyrimethamine with chemosuppression of $73.04 \%$ (Table 4 ).

Table 4. Effect of the methanol extract of Piper betle on residual malaria infection.

\begin{tabular}{lllll}
\hline Drug/extract & Dose & \% Parasitaemia & $\begin{array}{c}\text { \%Chemo- } \\
\text { suppression }\end{array}$ & Significance \\
\hline Control (dist. water) & $0.2 \mathrm{~mL}$ & $4.60 \pm 0.51$ & & \\
Piper betle Leaf extract & $50 \mathrm{mg} / \mathrm{kg}$ & $3.70 \pm 0.30$ & 19.57 & $\mathrm{~ns}$ \\
& $100 \mathrm{mg} / \mathrm{kg}$ & $3.00 \pm 1.34$ & 34.78 & $\mathrm{~ns}$ \\
& $200 \mathrm{mg} / \mathrm{kg}$ & $2.20 \pm 0.37$ & 52.17 & $P<0.05$ \\
& $400 \mathrm{mg} / \mathrm{kg}$ & $1.34 \pm 0.41$ & 70.88 & $P<0.001$ \\
Pyrimethamine & $1.2 \mathrm{mg} / \mathrm{kg}$ & $1.24 \pm 0.47$ & 73.04 & $P<0.05$ \\
\hline
\end{tabular}

\section{Experimental}

\subsection{Plant materials}

The plant part (leaves) of Piper betle was selected based on an ethnobotanical survey conducted by the Department of Parasitology, Faculty of Medicine, University of Malaya, in two malaria endemic communities, forest-aboriginal and rural communities, in the Lipis district of Pahang state, Peninsular Malaysia [9]. The plant has been recorded as a curative and prophylactic antimalarial remedy by the two communities. The voucher specimen was collected and identified by the University of Malaya Herbarium (KLU) and deposited under the reference number KLU 046620.

\subsection{Preparation of plant extract}

The leaves of Piper betle were dried in a hot air oven at $40{ }^{\circ} \mathrm{C}$ and milled. Five hundred grams of the powdered leaves was soaked with absolute methanol (3.5 L, Merck, Germany) for $72 \mathrm{~h}$. The extracts were concentrated in vacuo to dryness at $40{ }^{\circ} \mathrm{C}$ using a rotary evaporator. The percentage yield was $8.69 \%$. The dry extract was stored in a refrigerator at $4{ }^{\circ} \mathrm{C}$ until used. 


\subsection{Animals}

The animals (ICR mice), both male (27 $\pm 2 \mathrm{~g})$ and female (22 $\pm 2 \mathrm{~g}), 6-7$ weeks old which were used for these experiments were obtained from the Laboratory Animal Centre of the Faculty of Medicine, University of Malaya. The mice were housed in standard conditions and were maintained on a standard pelleted feed and water ad libitum. Permission and approval for animal studies were obtained from the Animal Ethics Committee of the Faculty of Medicine, University of Malaya dated 05 June 2009 (Ref. No. PAR/05/6/2009/AHAA-R).

\subsection{Phytochemical screening}

The chemical constituents of the leaf extract were tested for the presence of alkaloids, anthraquinones, terpenoids, flavonoids, tannins, steroids, saponins and glycosides using Dragendorff's reagent, sulphuric acid-chloroform layer test, Salkowski's test, ammonium test, lead sub-acetate reagent, Salkowski's test, frothing test and Fehling's reagent standard procedures, respectively [34,35].

\subsection{DPPH radical scavenging activity}

The antioxidant capacity of the extract was determined photometrically through its scavenging activity against the stable artificial free radical 1,1-diphenyl-2-picrylhydrazyl (DPPH), using the method of Gerhauser et al. [36]. In brief, DPPH $(195 \mu \mathrm{M})$ was added to different concentrations of the extract $(5 \mu \mathrm{L})$ in a 96-well microplate, and incubated for 3 hours and read at 20-min intervals. The bleaching of DPPH was observed at an absorbance of $515 \mathrm{~nm}$. Ascorbic acid and gallic acid were used for comparison. The free radical-scavenging activity was expressed as the percentage of scavenging of the DPPH by the extract and was calculated as follows:

DPPH radical scavenging activity $(\%)=\{[\mathrm{Ab}-\mathrm{Aa}] / \mathrm{Ab}\} \times 100$

where $\mathrm{Ab}$ is the absorption of the blank sample, and $\mathrm{Aa}$ is the absorption of the sample. Each test was carried out three times in quadruplicate and the mean was calculated. The DPPH \% was presented as $\mu \mathrm{g} / \mathrm{mL}$ of concentration.

\subsection{Median lethal dose}

Acute oral toxicity of the methanol extract of Piper betle leaves was studied according to the OECD guideline No 423 "Acute oral toxicity - acute toxic class method" [37]. A limit test was performed; one female and one male ICR mouse was administrated at $5,000 \mathrm{mg} / \mathrm{kg}$. Since these mice survived, four additional mice were sequentially dosed at approximately 48 to 72 -hour intervals. A total of five female and five male mice were tested. The mice were fasted overnight prior to administration and returned to feeding 3 hours later. On the day of extract administration, all the mice were observed for mortality and signs of toxicity at 1, 3 and 4 hours following administration and thereafter they were observed twice a day for 14 days. Body weights of the mice were recorded on study days $-1,0$ (initiation), 7 and 14 (termination). All experimental mice were sacrificed at the end of the observation period and subjected to complete gross necropsy and histopathological study. 


\subsection{Parasite inoculation}

Donor mouse blood infected with the $P$. berghei was used for inoculum preparation. The desired blood volume was drawn from the donor mouse by heart puncture and diluted serially in Alsever's solution. The final suspension would contain about $1 \times 10^{6}$ infected RBC's in every $0.2 \mathrm{~mL}$ suspension. This $0.2 \mathrm{~mL}$ suspension was injected into mice intraperitoneally to initiate infection [38]. The inoculated animals were then randomized into five mice per cage and maintained in the Animal Room, Department of Parasitology, Faculty of Medicine, University of Malaya, in accordance with the internationally accepted principles for laboratory animals use and care.

\subsection{In vivo antimalarial assays}

A series of in vivo antimalarial assays were carried out to evaluate the in vivo anti-malarial activities of the methanolic extract of Piper betle leaves at 50,100, 200 and $400 \mathrm{mg} / \mathrm{kg}$ doses as compared to control groups treated with distilled water (containing 10\% DMSO, the solvent of the test extracts) and reference groups treated with standard drugs (chloroquine $20 \mathrm{mg} / \mathrm{kg}$ or pyrimethamine $1.2 \mathrm{mg} / \mathrm{kg}$ ). Malaria infection was first established in female mice by the intraperitoneal (i.p.) administration of donor female ICR mouse blood containing about $1 \times 10^{6}$ parasites. The percentage parasitaemia was determined by counting the parasitized red blood cells out of $9000 \mathrm{RBC}$ 's in random fields of the microscope:

$$
\% \text { Parasitaemia }=\left[\frac{\text { No.of parasitized RBC }}{\text { Total no.of RBC counted }}\right] 100
$$

Average percentage chemosuppression was calculated as:

$$
100\left[\frac{\mathrm{A}-\mathrm{B}}{\mathrm{A}}\right]
$$

where $\mathrm{A}$ is the mean percentage parasitaemia in the negative control group and $\mathrm{B}$ is the mean percentage parasitaemia in the test group.

\subsubsection{4-day suppressive activity (early malaria infection)}

Suppressive activity of the extract was assessed using the method described by Peters and Robinson [39]. Thirty female ICR mice were first inoculated intraperitoneally with $0.2 \mathrm{~mL}$ suspension containing $1 \times 10^{6} \mathrm{P}$. berghei on the first day (D0). After 2-4 hours post-infection, the experimental groups were treated orally with $50,100,200$ and $400 \mathrm{mg} / \mathrm{kg} /$ day doses of the extract. The reference drug group was treated with chloroquine $(20 \mathrm{mg} / \mathrm{kg}$ ) and the control group received distilled water $0.2 \mathrm{~mL} / \mathrm{kg}$. All the treatments were repeated for the next three days (D1 to D3). On the fifth day (D4), thin blood smears were prepared from each mouse and stained with Giemsa's stain.

\subsubsection{Curative activity (established malaria infection)}

Thirty mice were selected and inoculum of $0.2 \mathrm{~mL}\left(1 \times 10^{6} \mathrm{P}\right.$. berghei $)$ was given to each mouse (i.p.). The mice were then regrouped into six groups of five mice each. Seventy-two hours later, the experimental groups were treated orally with 50,100, 200 and $400 \mathrm{mg} / \mathrm{kg} /$ day doses of the extract. The 
reference drug group was treated with chloroquine $(20 \mathrm{mg} / \mathrm{kg})$ and the control group received distilled water $0.2 \mathrm{~mL}$. The treatments were continued daily until D7. Thin blood smears were collected daily from tail blood, stained with Giemsa's stain and examined microscopically for determination of parasitaemia. On the sixth day of the infection, the mean percentage suppression of parasitaemia was calculated according to the procedure described by Ryley and Peters [40] and Saidu et al. [41]. The mean survival time (days) for each group was determined over a period of 30 days post-infection.

\subsubsection{Prophylactic activity (residual malaria infection)}

The prophylactic activity of the extracts was assessed using the method described by Peters [42]. The experimental mice were randomly divided into six groups of five mice each. The mice were administered orally with 50,100, 200 and $400 \mathrm{mg} / \mathrm{kg} /$ day of the extract, pyrimethamine $1.2 \mathrm{mg} / \mathrm{kg} / \mathrm{day}$ was administered to the reference drug group, and distilled water $0.2 \mathrm{~mL}$ to the control group. The treatment was given for 3 consecutive days (D0-D2). On the fourth day (D3), all mice were infected with $1 \times 10^{6} \mathrm{P}$. berghei and kept for the next 3 days. On D7, blood smears were prepared from the tail blood. The percentage of suppression of parasitaemia was then calculated.

\subsection{Statistical analysis}

All data were expressed as mean \pm S.D. and S.E.M. of triplicate parallel measurements. Statistical analysis was performed using Students' t-test and ANOVA (one- or two-way). Differences between means at 1 and $5 \%$ level $(P \leq 0.01$ and 0.05$)$ were considered significant.

\section{Conclusions}

The leaf extract of Piper betle demonstrated significant $(P<0.05)$ schizonticidal activity in all the three models of the antimalarial evaluations. The results of this study provide a basis for further studies on the plant. These include the isolation and characterization of the bioactive principles with the ultimate objective of finding novel antimalarial compounds which can be used in the fight against drug resistant malaria. This study also suggests that the Malaysian folkloric medicinal application of the extract of Piper betle leaves has a pharmacological basis.

\section{Acknowledgements}

The financial support of the University of Malaya (Grant codes PS275/2008A and PS204/2009C) is gratefully acknowledged. The authors thank the staff of the University of Malaya Herbarium for their fruitful help in the collection and identification of the plant species.

\section{References}

1. Randrianarivelojosia, M.; Rasidimanana, V.T.; Rabarison, H.; Cheplogoi, P.K.; Ratsimbason, M.; Mulholland, D.A.; Mauclère. P. Plants traditionally prescribed to treat tazo (malaria) in the eastern region of Madagascar. Malar. J. 2003, 2, 25, http://www.malariajournal.com/content/2/1/25.

2. Ridley, R.G. Plasmodium: Drug discovery and development-an industrial perspective. Exp. Parasitolo. 1997, 87, 293-304. 
3. Foster, S.D. Pricing, distribution, and use of antimalarial drugs. Bull. World Health Organ. 1991, 69, 349-363.

4. Ridley, R.G. Medical need, scientific opportunity and the drive for antimalarial drugs. Nature 2002, 415, 686-693.

5. Mishra, K.; Dash, A.P.; Swain, B.K.; Dey, N. Anti-malarial activities of Andrographis paniculata and Hedyotis corymbosa extracts and their combination with curcumin. Malar. J. 2009, 8, 26. doi:10.1186/1475-2875-8-26.

6. Ramazani, A.; Zakeri, S.; Sardari, S.; Khodakarim, N.; Dinparast, N. In vitro and in vivo antimalarial activity of Boerhavia elegans and Solanum surattense. Malar. J. 2010, 9, 124, doi:10.1186/1475-2875-9-124.

7. Botsaris, A.S. Plants used traditionally to treat malaria in Brazil: The archives of Flora Medicinal. J. Ethnobiol. Ethnomed. 2007, 3, 18, doi:10.1186/1746-4269-3-18.

8. Njoroge, G.N.; Bussmann, R.W. Diversity and utilization of antimalarial ethnophytotherapeutic remedies among the Kikuyus (Central Kenya). J. Ethnobiol. Ethnomed. 2006, 2, 8, doi:10.1186/1746-4269-2-8.

9. Al-Adhroey, A.H.; Nor, Z.M.; Al-Mekhlafi, H.M.; Mahmud, R. Ethnobotanical study on some Malaysian anti-malarial plants: A community based survey. J. Ethnopharmacol. 2010, 132, 362-364.

10. Nalina, T.; Rahim, Z.H.A. The Crude Aqueous Extract of Piper betle L. and its Antibacterial Effect towards Streptococcus mutans. Am. J. Biotech. Biochem. 2007, 3, 10-15.

11. Sarkar, A.; Sen, R.; Saha, P.; Ganguly, S.; Mandal, G.; Chatterjee, M. An ethanolic extract of leaves of Piper betle (Paan) Linn mediates its antileishmanial activity via apoptosis. Parasitol. Res. 2008, 102, 1249-1255.

12. Singh, M.; Shakya, S.; Soni, V.K.; Dangi, A.; Kumar, N.; Bhattacharya, S.M. The n-hexane and chloroform fractions of Piper betle L. trigger different arms of immune responses in BALB/c mice and exhibit antifilarial activity against human lymphatic filarid Brugia malayi. Int. Immunopharmacol. 2009, 9, 716-728.

13. Trakranrungsie, N.; Chatchawanchonteera, A.; Khunkitti, W. Ethnoveterinary study for antidermatophytic activity of Piper betle, Alpinia galanga and Allium ascalonicum extracts in vitro. Res. Vet. Sci. 2008, 84, 80-84.

14. Atta-ur-Rahman; Choudhary, M.I. Diterpenoid and steroidal alkaloids. Nat. Prod. Rep. 1995, 12, 361-379.

15. Jones, S.B.; Luchsinger, A.E. Plant Systematics; McGraw Hill Book Co.: New York, NY, USA, 1986.

16. Omulokoli, E.; Khan, B.; Chhabra, S.C. Antiplasmodial activity of four Kenyan medicinal plants. J. Ethnopharmacol. 1997, 2, 133-137.

17. Okokon, J.E.; Ita, B.N.; Udokpoh, A.E. Antiplasmodial activity of Cylicodiscus gabunensis. J. Ethnopharmacol. 2006, 2, 175-178.

18. Philipson, J.D.; Wright, C.W. Antiprotozoal compounds from plants sources. Planta Med. 1991, 57, 553-559. 
19. Francois, G.; Passreiter, C.M.; Woerdenbag, H.J.; Looveren, M.V. Antimalarial activities and cytotoxic effects of aqueous extracts and sesquiterpene lactones from Neurolaena lobata. Planta Med. 1996, 2, 126-129.

20. Ghoshal, S.; Prasad. B.N.; Lakshmi, V. Antiamoebic activity of Piper longum fruits against Entamoeba histolytica in vitro and in vivo. J. Ethnopharmacol. 1996, 50, 167-170.

21. Asase, A.; Akwetey, G.A.; Achel, D.G. Ethnopharmacological use of herbal remedies for the treatment of malaria in the Dangme West District of Ghana. J. Ethnopharmacol. 2010, 129, 367-376.

22. Kim, Y.C.; Kim, H.; Wataya, Y.; Sohn, D.H.; Kang, T.H.; Kim, M.S.; Kim, Y.M.; Lee, G.M.; Chang, J.D.; Park, H. Antimalarial Activity of Lavandulyl Flavanones Isolated from the Roots of Sophora flavescens. Biol. Pharm. Bull. 2004, 27, 748-750.

23. Monbrison, F.; Maitrejean, M.; Latour, C.; Bugnazet, F.; Peyron, F.; Barron, D.; Picot, S. In vitro antimalarial activity of flavonoid derivatives dehydrosilybin and 8-(1;1)-DMA-kaempferide. Acta Trop. 2006, 97, 102-107.

24. Tasdemir, D.; Kaiser, D.; Brun, R.; Yardley, V.; Schmidt, T.J.; Tosun, F.; Rüedi1, P. Antitrypanosomal and antileishmanial activities of flavonoids and their analogues: In vitro, in vivo, structure-activity relationship, and quantitative structure-activity relationship studies. Antimicrob. Agents Chemother. 2006, 50, 1352-1364.

25. Mahajan, S.S.; Kamath, V.R.; Ghatpande, S.S. Synergistic antimalarial activity of ketones with rufigallol and vitamin C. Parasitology 2005, 131, 459-466.

26. Amonkar, A.J.; Nagabhushan, M.; D'Souza, A.V.; Bhide, S.V. Hydroxychavicol: A New Phenolic Antimutagen from Betle Leaf. Food Chem. Toxicol. 1986, 24, 1321-1324.

27. Rimando, A.M.; Han, B.H.; Park, J.H.; Cantoria, M.C. Studies on the Constituents of Philippine Piper betle Leaves. Arch. Pharmacal. Res. 1986, 9, 93-97.

28. Nagabhushan, M.; Amonkar, A.J.; Nair U.J.; D'Souza, A.V.; Bhide, S.V. Hydroxy-Chavicol: A new anti-nitrosating phenolic compound from betle Leaf. Mutagenesis 1989, 4, 200-204.

29. Ganguly, S.; Mula, S.; Chattopadhyay, S.; Chatterjee, M. An ethanol extract of Piper betle Linn. mediates its anti-inflammatory activity via down-regulation of nitric oxide. J. Pharm. Pharmacol. 2007, 59,711-718.

30. Daubener, W.; Hucke, C.; Seidel, K.; Hadding, U.; Mackenzie, C.R. Interluekin-1 inhibits gamma interferon-induced bacteriostaisis in human uroepithelial cells. Infect. Immun. 1999, 67, 5615-5620.

31. United Nations. Globally Harmonized System of Classification and Labelling of Chemicals (GHS), 1st ed.; United Nations: Geneva, Switzerland, 2005.

32. Horn, H.J. Simplified LD50 (ED50) calculation. Biometrics 1956, 12, 311-322.

33. Muregi, F.W.; Ishih, A.; Miyase, T.; Suzuki, T.; Kino, H.; Amanod, T.; Mkoji, G.M.; Terada, M. Antimalarial activity of methanolic extracts from plants used in Kenyan ethnomedicine and their interactions with chloroquine (CQ) against a CQ-tolerant rodent parasite, in mice. $J$. Ethnopharmacol. 2007, 111, 190-195.

34. Sofowora, A. Medicinal Plants and Traditional Medicine in Africa, 2nd ed.; Spectrum Books Limited: Ibadan, Nigeria, 1993.

35. Trease, G.E.; Evans, W.C. Pharmacognosy, 13th ed.; Bailliere Tindall: London, UK, 1989; pp. 683-684. 
36. Gerhäuser, C.; Klimo, K.; Heiss, E.; Neumann, I.; Gamal-Eldeen, A.; Knauft, J.; Liu, J.U.; Sitthimonchai, S.; Frank, N. Mechanism-based in vitro screening of potential cancer chemopreventive agents. Mut. Res. 2003, 523-524, 163-172.

37. OECD (Organization for Economic Cooperation and Development). OECD Guidelines for Testing of Chemicals 423: Acute Oral Toxicity-Acute Toxic Class Method, 1st Adoption; Organization for Economic Cooperation and Development, Paris, France, 17 December 2001.

38. Ishih, A.; Suzuki, T.; Hasegawa, T.; Kachi. S.; Wang, H.H.; Terada, M. In vivo evaluation of combination effects of chloroquine with cepharanthin or minocycline hydrochloride against blood-induced choloquine-resistant Plasmodium berghei NK65 infections. Trop. Med. Health 2004, 32, 15-19.

39. Peters, W.; Robinson, B.L. The chemotherapy of rodent malaria XLVII: Studies on pyronaridine and other Mannich base antimalarials. Ann. Trop. Med. Parasitol. 1992, 86, 455-465.

40. Ryley, J.F.; Peters, W. The antimalaria activitiy of some quinoline esters. Am. J. Trop. Med. Parasitol. 1970, 84, 209.

41. Saidu, K.; Onah, J.; Orisadipe, A.; Olusola, A.; Wambebe, C.; Gamaniel, K. Antiplasmodial, analgesic, and anti-inflammatory activities of the aqueous extract of Erythrina senegalensis. J. Ethnopharmacol. 2000, 71, 275-280.

42. Peters, W. Drug resistance in Plasmodium berghei. Vinke and Lips 1948. I. Chloroquine resistance. Exp. Parasitol. 1965, 17, 80-89.

Sample Availability: Samples of the plant are available from the University of Malaya Herbarium (KLU) on request from the authors.

(C) 2010 by the authors; licensee MDPI, Basel, Switzerland. This article is an open access article distributed under the terms and conditions of the Creative Commons Attribution license (http://creativecommons.org/licenses/by/3.0/). 